\title{
NARCOLEPSY IN CHILDHOOD AND ADOLESCENCE
}

\author{
RUBENS REIMÃO * - HÉLIO LEMMI **
}

\begin{abstract}
SUMMARY - The objective of this study was to evaluate clinical, polysomnography and the multiple sleep latency test (MSLT) features in young narcoleptics. We evaluated 14 patients with mean age of 13.6 years old (ranging from 6 to 18 years); 11 were males and 3 females. Daytime sleepiness was the main complaint in all cases and started at the ages of 6 to 17 years. Cataplexy was described in 10 cases and it was considered mild to moderate in all but one case. Sleep paralysis was present in 6 cases and hypnagogic hallucinations in 7 cases. The main polysomnography characteristics were the short sleep latency in 9 cases and the sudden onset of REM periods in 7 cases. The MSLT showed short or borderline sleep latencies in 13 cases, with a mean of $4.9 \mathrm{~min} ; 2$ or more REM periods were present in 13 cases. Clinical, polysomnographic and MSLT characteristics in the age bracket focused were remarkably similar to those of adult narcoleptics suggesting the stability of these psysiopathological markers.
\end{abstract}

Narcolepsia na infância e adolescência

RESUMO - O objetivo deste estudo foi analisar características clínicas, polissonográficas e do teste das latências múltiplas do sono (TLMS) em crianças e adolescentes narcolépticos. Avaliamos 14 pacientes com média de idade de 13,6 anos (variando de 6 a 18 anos); 11 eram do sexo masculino, 3 do feminino. Sonolência excessiva diurna foi a queixa principal em todos os casos e principiou entre 6 e 17 anos de idade. Cataplexia foi descrita em 10 casos sendo leve em 9 destes. Paralisia do sono estava presente em 6 oasos e alucinação hipnagógiᄀ ca em 7 casos. A polissonografia mostrou duas características principais, a saber, a latência do sono reduzida em 9 casos e o início súbito de sono REM no princípio da noite em 7 casos. O TLMS mostrou a latência do sono reduzida ou limítrofe em 13 casos, com média de $4,9 \mathrm{~min}$. As características clínicas, polissonográficas e do TLMS na faixa etária aqui estudada foram semelhantes às do adulto, sugerindo a estabilidade de tais indicadores fisiopatológicos.

Narcolepsy is found in 2 to $7: 10,000$ individuais ${ }^{11} \gg{ }^{18}$, its evolution is chronic with incapacitating daytime sleepiness ${ }^{2}$. Most patients retrospectively recall its onset during adolescence, with a smaller number describing the start in childhood or in the third decade $₫$ ^25. However, there are few studies on this pathology in the first two decades of life $7,9,13,17,23-25$.

The objective of the present report is to describe clinical, polysomnographic and the multiple sleep latency test $(M S L T)^{5}$ features of a group of child and adolescent narcoleptics.

\section{METHODS}

We evaluated 14 narcoleptic patients (11 males, 3 females), the mean age was 13.6 years (ranging from 6 to 18 years) (Table 1). The diagnosis of narcolepsy was established based on a complete workup in two Sleep Disorders Centers, i.e., Baptist Memorial Hospital (BMH), Memphis, TN, USA (cases 1 to 12) and Albert Einstein Hospital (AEH), São Paulo,

* Sleep Disorders Center, Albert Einstein Hospital, São Paulo, Brazil; Sleep Disorders Center, Baptist Memorial Hospital, Memphis, TN, USA.

Dr. Rubens Reimão - Rua Glicineas 128 - 04048 São Paulo SP - Brasil. 
Brazil (cases 13 and 14). The assessment included clinical consultations, polysomnogram and MSL T 3,5,6,8. The cases described in this report represent 13 of 4,070 new patients evaluated at $B M H$ and 2 of 1,219 new patients evaluated at AEH. The main criteria for diagnosing narcolepsy were the presence of excessive daytime sleepiness, cataplexy, reduced sleep latency and presence of sleep-onset REM periods (SOREMP) in the MSLT 1.

All-night polysomnography included: electroencephalogram (C3/A2, C4/A1); electroculogram; electromyogram of submentalis and anterior tibialis muscles; buccal and nasal airflow measured by thermocouples; respiratory effort detected by thoracic pneumogram; electrocardiogram; continuous transcutanous oxygen saturation monitoring. Sleep staging followed the standardized criteria of Rechtschaffen and Kales 19. REM latency was always considered in relation to stage 1. SOREMP was used to denominate REM latencies shorter than 10 min. All patients were free of drugs for at least two weeks prior to the polysomnography, as well as for the MSLT. When repeated polysomnograms were recorded, we choose to present in this report only the best adapted night data.

MSLT normal parameters5,16,21 included the mean sleep latency of more than $10 \mathrm{~min}$ mean latencies between 5-10 min were considered borderline 12 . Whenever clinically applicable, two or more REM sleep episodes during the MSLT trials in a single day were considered as suggestive of narcolepsy 15,16

\section{RESULTS}

The 14 narcoleptic patients evaluated had a mean age of 13.6 years (range, 6 to 18 years); 11 were males and 3 females (Table 1). In all cases, the excessive daytime sleepiness was the main complaint and the first symptom to present, starting when they were 6 to 17 years olds (mean of 11.7 years). Time between the onset of sleepiness and the diagnosis of narcolepsy varied from 3 months to 8 years (mean of 1.6 years). Cataplexy was present in 10 cases. In only one patient (case 13), cataplexy had such intensity and frequency that prevented regular school attendance and home daily activities.

\begin{tabular}{|c|c|c|c|c|c|c|c|c|c|c|c|c|c|c|}
\hline & \multicolumn{14}{|c|}{ Case numbers } \\
\hline & 1 & 2 & 3 & 4 & $\mathbf{5}$ & 6 & 7 & 8 & 9 & 10 & 11 & 12 & 13 & 14 \\
\hline Age (years) & 18 & 18 & 18 & 9 & 6 & 14 & 18 & 11 & 12 & 10 & 11 & 16 & 13 & 17 \\
\hline $\operatorname{Sex}$ & $\mathbf{F}$ & $\mathbf{M}$ & $\mathbf{M}$ & $\mathbf{M}$ & $\mathbf{M}$ & $\mathbf{M}$ & $\mathbf{M}$ & $\mathbf{M}$ & $\mathbf{F}$ & $\mathbf{M}$ & $\mathbf{F}$ & $\mathbf{M}$ & $\mathbf{M}$ & $\mathbf{M}$ \\
\hline EDS & + & + & - & + & + & + & + & + & + & + & + & + & + & + \\
\hline Age of EDS onset (years) & 14 & 17 & 15 & 9 & 6 & 13 & 17 & 11 & 11 & 9 & 10 & 12 & 11 & 9 \\
\hline Cataplexy & + & 一 & + & + & 一 & $t$ & 一 & - & + & $t$ & + & + & $\dot{t}$ & + \\
\hline Sleep paralysis & + & - & 一 & + & + & 一 & + & - & 一 & + & 一 & - & + & -- \\
\hline Hypnagogic hallucinations & 一 & - & $\dot{+}$ & + & + & 一 & 一 & + & 一 & 一 & - & + & + & + \\
\hline
\end{tabular}

Table 1 - Demographic and clinical data of 14 narcoleptic children and adolescents. EDS, excessıve daytime sleepiness.

Table 1 - Demographic and clinical data, of 14 narcoleptic children and adolescents. EDS, excessive daytime sleepiness.

Sleep paralysis was reported in 6 cases and hypnagogic hallucinations in 7 cases. Of all 14 patients, only two had the complete narcoleptic tetrad.

The most characteristic polysomnography findings were the short sleep latency in 9 cases and SOREMP in 7 cases (Table 2). Sleep efficiency, or the percentage of total time in bed that is spent asleep, was low in 7 oases. The number of awakenings was remarkably high for this age bracket 22,8 patients having more than 5 awakenings. The number of brief arousals was also characteristically high, and in one patient (case 11) the arousals were related to periodic movements in sleep (PMS), showing 15.4 arousals per hour (normal up to $2.5 / \mathrm{h} 20$ ).

MSLT data (Table 2) showed sleep latency in the normal range (more than 10 min) in only one patient (case 1). This 18 years-old girl had a complete clinical picture of narcolepsy that did not differ from the other patients in this group, with severe daytime sleepiness for the last 4 years, clear-cut cataplexy and sleep paralysis ${ }^{\wedge}$ She also did not show REM sleep periods in the MSLT. 
Case numbers

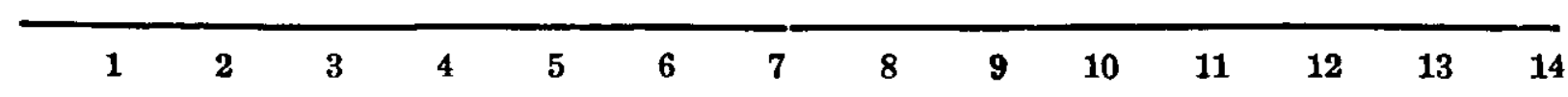

Polysomnography

Total time in bed (min)
Total sleep time (min)
Total sleep time (\%)
Body movements

Arousals

Awakenings

Sleep latency (min)

Stage $1(\%)$

Stage $2(\%)$

Stage $3(\%)$

Stage 4 (\%)

Stage REM (\%)

REM density (\%)

REM latency (\%)

MSLT

Mean sleep latency (min)

Number of SOREMP/Trials

\begin{tabular}{|c|c|c|c|c|c|c|c|c|c|c|c|c|c|}
\hline 478 & 504 & 501 & 454 & 546 & 533 & 526 & 518 & 619 & 536 & 534 & 433 & 440 & '446 \\
\hline 447 & 482 & 489 & 281 & 427 & 517 & 519 & 414 & 492 & 515 & 518 & 390 & 425 & 396 \\
\hline 93.5 & 95.6 & 97.6 & 61.8 & 78.2 & 96.9 & 98.6 & 79.9 & 79.4 & 96.0 & 97.0 & 90.9 & 96.5 & 88.7 \\
\hline 27 & 40 & 72 & 76 & 44 & 30 & 42 & 50 & 75 & 31 & 29 & 75 & 49 & 19 \\
\hline \multirow[t]{2}{*}{4} & 6 & 7 & 11 & 20 & 41 & 38 & 64 & 53 & 18 & 133 & 12 & 39 & 31 \\
\hline & 4 & 2 & 8 & 17 & 6 & 2 & 17 & 11 & 1 & 8 & 7 & 1 & 9 \\
\hline 31 & 7 & 3 & 88 & 1 & 5 & 4 & 1 & 4 & 8 & 3 & 5 & 8 & 20 \\
\hline 4.6 & 4.9 & 8.7 & 7.8 & 18.2 & 11.6 & 2.7 & 6.2 & 6.3 & 2.9 & 10.4 & 12.0 & 0.7 & 2.7 \\
\hline 61.5 & 54.9 & 48.2 & 39.1 & 34.8 & 55.5 & 49.1 & 50.7 & 18.9 & 52.6 & 43.6 & 48.2 & 11.0 & 61.3 \\
\hline 4.9 & 4.5 & 10.6 & 22.7 & 11.4 & 5.9 & 13.2 & 6.2 & 10.7 & 4.8 & 5.7 & 4.3 & 2.8 & 2.2 \\
\hline 8.9 & 13.9 & 10.6 & 23.1 & 21.5 & 9.8 & 12.5 & 18.1 & 32.7 & 13.9 & 15.8 & 17.4 & 58.8 & 10.6 \\
\hline 19.9 & 21.9 & 2.1 .6 & 7.1 & 13.8 & 17.0 & .22 .3 & 18.6 & 31.3 & 25.6 & 24.3 & 17.9 & 26.5 & 22.9 \\
\hline 12.8 & 19.2 & 16.2 & 12.5 & 13.7 & 18.2 & 25.0 & 16.8 & 18.1 & 5.3 & 12.7 & 5.7 & 8.9 & 11.4 \\
\hline 75 & 3 & 1 & 85 & 1 & 4 & 99 & 1 & 7 & 120 & 112 & 184 & 5 & 63 \\
\hline 12.0 & 6.6 & 2.7 & 7.2 & 4.7 & 2.5 & 7.7 & 2.0 & 2.5 & 2.0 & 3.2 & 1.0 & 0.8 & 4.6 \\
\hline $0 / 5$ & 3/3 & $3 / 4$ & $5 / 5$ & $4 / 5$ & $3 / 3$ & $2 / 4$ & $3 / 3$ & $3 / 3$ & $3 / 4$ & $2 / 5$ & $3 / 3$ & $4 / 5$ & $2 / 5$ \\
\hline
\end{tabular}

Table 2-Polysomnographic and multiple sleep latency test (MSLT) data oj narcoleptic children and adolscents. SOREMP, sleep-onset REM period. 
The presence of 2 or more REM periods in the MSLT was detected in 13 cases; 3 or more REM periods were seen in 10 cases. The number of REM periods in the MSLT was not correlated with age nor with duration of the symptoms.

\section{COMMENTS}

The age of onset found in our patients corresponds to that most usually retrospectively described by narcoleptic adults 25 . The first symptom is generally the excessive daytime sleepiness in most narcoleptic adults and children ${ }^{25}$ Kotagal \& col. ${ }^{13}$ reported that the mean age at onset of excessive sleepiness was 10.2 years, in a group of preteenaged narcoleptics, which is similar to the mean age of 11.7 years seen in our group.

The complete narcoleptic tetrad was present in only $14.2 \%$ of our patients. Such finding is similar to the $25 \%$ noted in adults and children 23 . $i_{n}$ our patients, the presence of a complete tetrad did not correlate with age of onset, polysomnography or MSLT findings.

Nocturnal polysomnographic findings in the group here described • included SOREMP which is also present in adult nacoleptics. SOREMP was present in 50.0\% of our patients and in $63.0 \%$ of children with narcolepsy described by others ${ }^{25}$. The mean REM latency in the present group of children and adolescent narcoleptics was 54.2 min but in a previous study with adult narcoleptics we observed mean latency of $47.1 \mathrm{~min} 14$.

The sleep efficiency reduction and the increase in number of awakenings and arousals are usual findings in adults and children with narcolepsy ${ }^{13}{ }^{16}$, similar to the findings in our group. They suggest an instability in sleep maintenance mechanisms similar to the instability of daytime alertness maintenance mechanisms that characterizes narcolepsy.

PMS has been described associated with several sleep disorders including narcolepsy in adults ${ }^{20}{ }^{25}$, and in few reports in children ${ }^{12}>^{25}$. PMS is most usually found after the third decade of life so, the presence of an 11-year old narcoleptic boy in our sample which myoclonus are highly related with arousals supports the possibility of an early disruption of sleep architecture by PMS. However, relationship between PMS and narcolepsy remains obscure.

The MSLT data with two or more REM periods is usually interpreted as suggestive of narcolepsy ${ }^{15} \ll^{16}$. That happened in $92.9 \%$ of our patients indicating the high sensitivity of the method in such an early age, as it was previously found in a group of preteenaged narcoleptic children ${ }^{13}$. The short sleep latency was also found in $92.9 \%$ of our group and $71.4 \%$ had latencies shorter than 5 min. Such data is similar to that noted in narcoleptic adults as well as children ${ }^{25}$.

Clinical, polysomnographic and MSLT features here described in child and adolescent narcoleptics show a marked similarity with those of adult patients. They suggest a long-term stability of these physiopathological markers in narcolepsy.

Acknowledgement - We are indebt with Joseph Belluomini and Sharon Burt (BMH) for technical assistance and support.

\section{REFERENCES}

1. Association of Sleep Disorders Center. Diagnostic classification of sleep and arousal disorders. Sleep 1979, 2:1.

2. Broughton R, Ghanem Q, Hishikawa Y, Sugita Y, Nevrismalova S, Roth B. Life effects of narcolepsy: relationships to geographic origin (North American, Asian or European) and to other patient and illness variables. Can J Neurol Sci 1983, 10:100.

3. Carskadon MA. Ontogeny of human sleepiness as measured by sleep latency. In Dinges DF, Broughton RJ (eds): Sleep and Alertness: Chronobiological, Behavioral and Medical Aspects of Napping. New York: Raven Press, 1989.

4. Carskadon MA. The second decade. In Guilleminault C (ed): Disorders of Sleeping and Waking: Indications and Techniques. Menlo Park; Addison-Wesley Publ, 1982. 
5. Carskadon MA, Dement WC, Mitler MM, Roth T, Westbrook PR, Keenan S. Guidelines for the multiple sleep latency test (MSLT): a standard measure of sleepiness. Sleep $1986,9: 519$

6. Carskadon MA, Harvey K, Dement WC. Sleepiness in young adolescents. Sleep 1981, $4: 229$.

7. Carskadon MA, Harvey K, Dement WC. Multiple sleep latency test in the development of narcolepsy. West J Med 1981, 135 : 414.

8. Carskadon MA, Orav EJ, Dement WC. Evolution of sleep and daytime sleepiness in adolescents. In Guilleminault C, Lugaresi E (eds): Sleep/Wake Disorders: Natural History, Epidemiology and Long-Term Evolution. New York: Raven Press, 1983.

9. Chisolm RC, Brook CJ, Harrison GF. Prepubescent narcolepsy in a 6-year-old child Sleep Res 1985, $15: 113$

10. Cowan R, Reimão R, Lemmi H, Vander Zwaag R. Narcolepsia e início súbito de períodos REM após despertares noturnos. Arq Neuro-Psiquiat (São Paulo) 1985, 43 : 229.

11. Dement WC, Carskadon MA, Ley R. The prevalence of narcolepsy. Sleep Res 1973, $2: 147$.

12. Hoed JVD, Kraemer H, Guilleminault C. Disorders of excessive daytime somnolence: polygraphic and clinical data for 100 patients. Sleep 1981, 4:23.

13. Kotagal S, Hartse KM, Walsh JK. Characteristics of narcolepsy in preteenaged children. Pediatrics 1990, $85: 205$

14. Lemmi H, Reimão R, Cowan R, Appavoo S, Vander Zwaag R. Sleep onset REM periods after spontaneous awakenings and the diagnosis of narcolepsy. Sleep Res 1985, 14:186.

15. Mitler M. The multiple sleep latency test as an evaluation for excessive somnolence. In Guilleminault C (ed): Disorders of Sleeping and Waking: Indications and Techniques. Menlo Park: Addison-Wesley Publ, 1982.

16. Mitler MM, Hoed JVD, Carskadon MA, Richarson G, Park R, Guilleminault C, Dement WC. REM sleep episodes during the multiple sleep latency test in narcoleptic patients. Electroenceph Clin Neurophysiol 1979, 46:479.

17. Nevrismalova S, Roth B, Zouhar A, Zemanova H. Narcolepsy-cataplexy and periodic hypersomnia in infancy. Electroenceph Clin Neurophysiol 1987, $67: 21$.

18. Nevrismalova-Bruhova S, Roth B. Heredofamilial aspects of narcolepsy and hypersomnia. Schw Arch Neurol Neurochir Psychiatr 1972, 110 : 45.

19. Rechtschaffen A, Kales A. Manual of Standardized Terminology, Techniques and Scoring for Sleep Stages of Human Subjects. Los Angeles: Brain Information Service, University of California, 1968.

20. Reimão R, Lemmi H, Belluomini J. Aspectos poligráficos dos movimentos periódicos do sono. Arq Neuro-Psiquiat (São Paulo) 1984, 42 : 313.

21. Richardson RS, Carskadon MA, Flagg W, Hoed JVD, Dement WC, Mitler MM. Excessive daytime sleepiness in man: multiple sleep latency measurement in narcoleptic and control subjects. Electroenceph Clin Neurophysiol 1978, $45: 621$.

22. Williams RL, Karacan I, Hursch CJ (eds): EEG of Human Sleep. New York: John Wiley \& Sons, 1974.

23. Wittig R, Zorick F, Roehrs T. Narcolepsy in a 7-year-old child. J Pediatr 1983, $102: 725$.

24. Yoss RE, Daly DD. Narcolepsy in children. Pediatrics 1960, $25: 1025$.

25. Young D, Zorick F, Wittig R, Roehrs T, Roth T. Narcolepsy in a pediatric population Am J Dis Childh 1988, $142: 210$. 